of the observations of sun-spots made by the late Dr. C. H. Peters, extending over the period $1860-1870$, and including the determination of more than 13 , 000 heliographic positions of spots on more than I roo days; a paper by Prof. W. H. Pickering on planetary inversion, which the author illustrated by experiments with a gyroscope; and an account of the foundation, and the partial destruction by fire, of the Philadelphia Observatory, by Prof. M. Snyder.

Solar Prominences puring 1905.-The usual annual summary of the prominence observations carried out at the Catania Observatory during the past year is published by Prof. Mascari in No. 4, vol. xxxv., of the Memorie della Società degli Spettroscopisti Italiani.

The results show that the mean daily frequency of prominences observed was greater in 1905 than in 1904 and 1903 , but the increase was not so great as might have been expected. As in previous years, it is seen that the increase in mean daily frequency corresponds with a decrease in heliographic latitude. In 1904 the mean daily frequency was 2.90 and the mean latitude $36^{\circ} \cdot 6$, whilst for 1905 the corresponding figures were 3.05 and $30^{\circ} .8$. The mean altitude of the prominences during 1904 was $43^{\prime \prime} \cdot 7$, and in 1905 it was $44^{\prime \prime} \cdot \mathrm{I}$; the corresponding extensions of the prominences along the solar limb were $7^{\circ} \cdot 27$ and $8^{\circ} \cdot 77$.

The greater frequency of prominences in the sun's northern hemisphere still persists, the values for 1905 being $\mathrm{I} \cdot 77$ for the northern and $\mathrm{I} \cdot 28$ for the southern hemisphere.

The Period of $\beta$ Lyre.-Referring to the recent note by $\mathrm{Mr}$. Roberts on the increasing period of $\beta \mathrm{Lyr}_{w}$, Prof. Schaeberle suggests another possible cause which may account for that phenomenon.

It is now generally accepted that incandescent bodies have the power of repelling fine particles of their component matter to great distances, and Prof. Schaeberle suggests that, at a certain stage in the life-history of such a body, the decrease in mass may be so rapid as to cause an increase in the periodic time of any other body belonging to the system. If part of the ejected mass afterwards returns to the parent body other changes will obviously occur (Observatory, No. 370).

\section{THE SIXTH INTERNATIONAL CONGRESS OF APPLIED CHEMISTRY.}

WHEN the International Congress of Applied Chemistry, assembled at Berlin in 1903 , chose Rome as its next meeting-place, the fear was expressed by some that the Italian chemical industry might not perhaps be of sufficient magnitude to ensure a large attendance at the next congress. The brilliant success of the meeting which has just terminated has shown, however, that these fears were entirely without justification, and the number of important communications from the Italian members of the congress proves the reality of the progress which Italy has made of late years in chemical industry.

The meeting was opened on April 26 under the most favourable auspices by the King and Queen in person, accompanied by the Minister of Public Instruction and other high officials. The place of meeting was the magnificent Palace of Justice, then brought into use for the first time; in fact, it is not yet wholly completed as regards the internal decorations. There being a large number of rooms in the building, space was easily found for the sixteen sections into which the congress was compelled to subdivide itself. The number of British members was more than thirty, and on the whole the attendance from other countries was very satisfactory, even China being represented. It is somewhat of a novelty to hear speeches in Chinese at European scientific meetings, and shows that the awakening of the Celestial Empire is becoming an accomplished fact. Such a congress is an interesting study in ethnology as well as philology. Officially only four languages are supposed to be used, namely, English, French, German, and Italian; but the greatest leniency is shown in this respect, and the reporters must sometimes rely on summaries made by the speakers themselves.

Among the papers read before the full meeting of the congress the most important was undoubtedly Dr. Adolph Frank's description of his process for the direct utilisation No. I907, vol. 74$]$ of the nitrogen of the atmosphere for the production of artificial manure and other chemical products. Dr. Frank's invention is not only ingenious, but its effects on the future of the human race will probably be of the greatest importance. The inventor is a veteran in agricultural chemistry; he it was who, more than fifty years ago, introduced the potash salts of Stassfurt to the notice of agriculturists. Now nearly three million tons of these salts are used annually by agriculturists all over the world. The problem of the fixation of atmospheric nitrogen has often been attacked, for the first time on a large scale during the French Revolution. At that time France, surrounded by her enemies, was cut off from the supply of saltpetre necessary for national defence. A committee of French chemists then established the saltpetre farms where the nitrifying organisms, with which we have since become more intimately acquainted, produced the necessary means of defence. We in Great Britain, however, are still entirely dependent upon foreign sources for the explosives necessary for our national defence, and it is only by the establishment of some such process as Dr. Frank's in Great Britain that we shall place ourselves in safety in this respect. The invention is not a complicated one, the difficulties consisting chiefly in the solution of new problems of chemical engineering. Calcium carbide is first produced and then heated with nitrogen obtained by the fractional distillation of liquid air. During this distillation oxygen is obtained as a by-product, and may be utilised for the production of nitric acid from ammonia, which, again, is one of the substances produced by Dr. Frank. The first raw material obtained is calcium cyanamide, and it is this that is used as a nitrogenous manure, numerous experiments having shown that the nitrogen which it contains can be easily assimilated by plants. For countries such as Italy, and more especially India, with large agricultural populations who do not possess sufficient cattle to supply the requisite nitrogenous manure, this direct utilisation of the inexhaustible nitrogen of the atmosphere cannot fail to be of enormous importance; but to the chemist the calcium cyanamide has other attractions. From it have been produced, not only ammonia and nitric acid, but also urea and guanidine. We are therefore on the high road towards the artificial production of the alkaloids, and the next step will probably be the building up of substances directly assimilable by human beings, in other words, artificial foods.

But while chemists revelled in these anticipations they did not forget more practical subjects. An excellent paper by Sir William Ramsay gave a clear and exhaustive account of the present state of the sewage question in Great Britain. Special attention was given by the author to the bacterial methods of sewage disposal which are now being so widely adopted. M. Moissan, whose work with the electric furnace is so well known, gave the results of his experiments on the distillation of metals. All metals, indeed all substances, are volatile at a temperature below $3500^{\circ} \mathrm{C}$., therefore M. Moissan draws the conclusion that the temperature of the sun cannot exceed this; it must, indeed, be somewhat less, as the bulk of the elements of which it consists are volatile at a lower temperature than the maximum mentioned. No doubt the data with which Prof. Moissan has furnished chemists will be utilised for practical purposes, especially in the purification of metals.

Many of the papers read before the various sections contained matter of great scientific interest. The report of the International Committee on the Unification of Analytical Methods was presented by Dr. Lunge, and will be of great assistance to analysts in different countries who wish to secure uniform results. Prof. W. N. Hartley's paper on the use of the spectrograph in analysis aroused much interest in the photographic section. It is certainly a great advantage to be able to make a quantitative analysis of a rare object in metal without defacing it in any way, and the convenience of the method will no doubt ensure it general acceptance when it becomes better known. Another communication made to the inorganic chemistry section was of interest, inasmuch as it holds out hopes of a considerable reduction in the price of photographic and other glass of high quality. Hitherto such glass has been made in the expensive pot furnaces, but the author of the paper, Herr F. Heller, states that he has succeeded in making 
such glass in the cheaper tank furnaces. In order to do this he divides the melting operation into three phases, each of which is carried out in a separate tank furnace at a definite temperature. The raw materials are first melted down at about $1400^{\circ} \mathrm{C}$., the fused mass is then run into a second furnace at about $1200^{\circ} \mathrm{C}$., in which the glass is clarified, and finally the clear glass is run into a working tank furnace of about $1000^{\circ} \mathrm{C}$. The hope was expressed that the principle might be applied to optical glass of high quality. To the same section Sir William Ramsay contributed a paper on the Bischof process for manufacturing white lead, one of the chief advantages of which is that the workpeople are not exposed to the deleterious action of the dust which renders such stringent precautions necessary in other works. Messrs. G. Giorgis and G. Gallo contributed an essay on the hydraulic properties of various kinds of puzzuolanas, between some of which there are great differences both in time of setting and in the ultimate strength attained. The subject is of great importance in Italy, where puzzuolana mortars largely replace those made in other countries with Portland cement. Sands of the nature of puzzuolana are to be found in other volcanic countries, and merit more attention than they have hitherto received. The remarkable state of preservation of the old Roman buildings in Italy is largely due to the fact that the mortar used in their construction was hydraulic.

The sulphur industry being of such importance to Italy, it was to be expected that it would receive considerable attention. Mr. B. Reinitzer discussed the origin of natural deposits of sulphur, and Prof. N. Rossi described a new method of extracting poor sulphur ores by means of bisulphide of carbon. It was stated that there are very considerable quantities of sulphur ores containing less than 20 per cent. of sulphur, below which percentage it is not at present remunerative to work them. The author proposes to lixiviate these by means of bisulphide of carbon, and has designed plant for that purpose. It must be remarked, however, that similar efforts have hitherto resulted in failure, and the author's apparatus met with some adverse criticism by chemical engineers familiar with such subjects. It is to be hoped that a practicai test may be made with the apparatus, as the Sicilian sulphur industry is being seriously threatened by the discovery of the Louisiana deposits.

Prof. L. Ricciardi, of Naples, communicated the results of a number of analyses of eruptive rocks, from which he draws the important conclusion that volcanoes at first emit rocks of an acid nature, but that subsequently the products are basic in their character. The author is of opinion that volcanic phenomena are similar throughout the world, and the rocks which give rise to them are granitic in their nature.

Prof. A. C. Vournasos, of Athens, reported the discovery of a large deposit of asphalt in Greece, which is already being worked on an industrial scale, and appears to be a valuable addition to our supplies of that useful substance. At the same time the author communicated a new method for testing asphalt which he had recently devised.

The section of the congress dealing with the industry and chemistry of sugar was the medium for the communication of a large number of papers, chiefly of industrial interest. Nearly every European country except Groat Britain has now a large sugar industry; in fact, the International Congress of Applied Chemistry originated in a meeting of chemists engaged in the sugar industry. A paper by Mr. C. H. Neumann on the testing of the germinating power of sugar-beet seeds shows the amoun of specialisation which has taken place. The author found that the best medium for ensuring the regular germination of the seeds was a damp mixture of sand and sawdust, the temperature being carefully regulated.

In the section on explosives Mr. R. Villanis presented a detailed memoir on the state of the explosives industry in Italy in which the various factories and their products were described, together with the regulations in force. The erosion and corrosion of firearms by smokeless powders gave rise to two communications by Dr. V. Reuhi and by $\mathrm{Mr}$. Gey van Pittius. The former referred to the use of nitro-guanidine as an explosive, this being one of the products of Frank's discovery mentioned already.
Several authors dealt with the use of alcohol and petroleum products as sources of power. In Great Britain, where petroleum is admitted free of duty, there can be no doubt that it is at present the cheapest liquid in use for the production of power. Some Continental countries, however, in order to foster the alcohol industry and the important agricultural interests depending upon it, have imposed heavy duties on all competing liquids, and there is naturally continuous rivalry between the various interests thus created.

The section dealing with wine was also of more importance to Continental than to British members, and the same may be said of the agricultural chemistry section, in which matters connected with Continental husbandry were fully discussed. Prof. J. Stoklasa dealt with the enzymes which produce lactic and alcoholic fermentation in the tissues of plants. The author agreed with Messrs. C. Golenski and Mazé that such fermentation is in reality the intramolecular respiration of plants, and a number of experiments were described corroborating this view.

The final plenary sitting of the congress was mainly occupied in passing resolutions confirming recommendations by the sectional committees. Among these may be mentioned the appointment of a committee to elaborate uniform methods of testing explosives, the unification of methods of sugar analysis, especially between the Custom House officials of different countries, and the unification of methods for the analysis of malt in breweries. The transport of dangerous substances by rail was also referred to, and recommendations made as to the patenting of inventions by employees and upon international trade marks.

At the close of the meeting an invitation to the congress to meet in London in 1909 was given by Prof. Tilden, as representing the British Government, and Dr. L. Mond, Prof. E. Divers, and Prof. R. Meldola as representing a joint committee, consisting of practically every British society connected with chemistry, which had been formed on the initiation of the Society of Chemical Industry. The invitation was unanimously accepted.

During the session of the congress a number of social gatherings and excursions took place which afforded excellent opportunities for the delegates of the various nations to become acquainted with each other. The largest excursion was to Tivoli, where about I500 members were present. The beauties of that lovely. spot are too well known to require description, but the remarks of some of the electrochemists led one to believe that they considered a large amount of water-power was being wasted. It would be well, in view of the utilitarian character of modern industry, if the different States were to secure one or two of their most picturesque waterfalls before they have all been absorbed for the production of electrical energy. Many members of the congress visited the sad scenes in the neighbourhood of Vesuvius. One member who had collected the volcanic dust, soon after the eruption, at Addlestone, in the Thames valley, and again on a roof at Turin, was enabled to satisfy himself of the identity of these specimens with the Naples dust.

Excursions were proposed to Sicily and to Elba, but ar. inopportune strike of the sailors of the Italian Steam Navigation Company put an end to these. Many who were visiting Rome for the first time found many objects of interest, apart from the inexhaustible art treasures of the city. One naturalist collected three varieties of Helix on the walls of the castle of St. Angelo, while a botanist directed attention to the presence of pellitory of the wall on the same building. English tradition says that it was introduced into England by monks, and in some districts it is only found on old monastic buildings. In some rubbish that was being cleared out of the dungeons of St. Angelo numerous fragments of marble cannon-balls were found. During times of siege it is related that large numbers of statues were converted into cannon-balls, and the great variety of marbles to be found among the fragments lends support to this statement. Another enthusiastic lover of nature in all her forms collected a number of live scorpions in the Forum. He stated that they soon became tame, and took live ants from the fingers. His statements were accepted without discussion.

The meeting of the congress was brought to a close on May 5 by a state banquet given by the King of Italy at

NO. I 907 , VOL. 74] 
the Quirinal to the delegates of foreign. Governments and societies. Both the King and Queen received the visitors, among whom were six British delegates. After the banquet the King, who takes great interest in the industrial revival now taking place in Italy, held a reception, several of the Italian ministers being present. The next day most of the members of the congress departed from the beautiful and hospitable city which had been the scene of their labours, many with the intention of returning if possible.

\section{THE SURVEY OF INDIA.}

THE report ${ }^{1}$ of the Indian Survey Committee recently received is contained in two volumes, the size of which should be sufficient testimony to the exhaustive nature of the inquiry. The result, on the whole, should be satisfactory to those who for years past have been protesting against the short-sighted policy of the Indian Government, which, under financial pressure, has often forced reductions on the Survey Department until its efficiency has become seriously impaired. There is hardly a reform suggested by the committee which has not been urged previously in India. Sir John Farquharson (president of the committee, whose death so soon after his return to England was almost tragic) but expressed the opinions of many who have been closely associated with the Indian Survey Department, modified more or less by his own experiences as chief of the Ordnance Survey in England.

The main results of the committee's recommendations are, first, the strengthening of the department in men and money, and secondly, the separation of the cadastral (or revenue) from the topographical and trigonometrical branches in order that proper supervision may be given to the latter, and that the general military maps of the peninsula and the frontier may be brought (and kept) up to date. Cadastral surveys will in future be relegated to local governments, who will be responsible for the main tenance of their own revenue maps; but scientific supervision of this local work will be provided from the depart. ment. This indeed is essential, as everybody knows who has had experience of the terrible results of local meddling with original survey mapping by half-trained, or wholly ignorant, native employees. Nor is the fact overlooked that all the extreme refinement of the most accurate geodetic triangulation has its final expression in these revenue maps. The larger the scale and the more restricted the area, the greater the necessity for a positively accurate basis for local traversing. Every little village plan must take its place accurately in the provincial map if titles to property are to be of any account.

The recommendations of the committee regarding the topographical mapping of India and the reproduction of maps appear on the whole to be excellently well adapted to the end in view, in spite of a certain amount of dissent in matters of detail recorded by the present Surveyor-General. Due acknowledgment is made to the late Surveyor-General (Colonel Gore) for the accuracy of his estimate of the amount of revision necessary, and the cost in time and money of carrying it out ; and $a^{\prime}$ most appropriate despatch from a former Secretary of State for India (1876) is quoted, in which the fallacy of expecting to effect economies by the reduction of well-trained survey parties is emphatically maintained. That fallacy was, however, supported by the then Government in India, and was supported by every Government since, until the arrival of a geographical expert as Viceroy in Lord Curzon. The topographical maps of all India, on the I-inch per mile scale, are to be thoroughly revised and completed. It is something of a surprise that mapping on this scale was not completed long ago, as there has been nothing important missing from the general map of India for several years past. The method of reconstruction recommended by the committee is not altogether approved by the present Surveyor-General, who is in favour of more decentralisation in order to gain efficient supervision; but there was no dispute as to the paramount necessity of maintaining one standard map of

1 " Report of the Indian Survey Committee, 1904-5." Part i., The Report, pp. vi+15r. Part ii., pp. v+223. (Simla: The Government
Central Printing Office, 1905.) the whole of India in a state of absolute completeness. Nor can the recommerdations with reference to frontier mapping be regarded with anything but satisfaction. The appointment of a special superintendent on the frontier to rank with the superintendent of trigonometrical surveys, with five working parties under him, and three officers attached to each party, and with the headquarters office at Simla in touch with the Intelligence Department, is indeed a big concession to military requirements. A similar, but much smaller, scheme was suggested nearly ten years ago, in the days when two or three officers and one elastic party were considered ample to deal with the Indian borderland from the Indus to the Euphrates; but it was not entertained. Trans-frontier surveys, apart from political boundary requirements, were not recognised as of any importance. It depended entirely on the enterprise of the officer in charge of the frontier party whether any such work was carried out at all; it was regarded as rather beyond the scope of strict departmental business-to be permitted (if no complications with tribes-people were involved), but hardly to be approved.

Any effort to render frontier mapping more effective by ensuring its proper distribution amongst the military offices of the frontier was perhaps beyond the scope of the committee's proceedings, but it can hardly be denied that proper map distribution is only second in importance to map making.

The reproduction of maps has always been the great difficulty of the Indian Survey Department. Climate, material, and personnel are all against the reproduction of clear, readable, and artistic maps from the excellent material which is found in the original field-sheets. Dr. Stein's evidence on this point is very suggestive. Whilst condemning the printed maps, he paid a graceful tribute to the artistic value of the originals. Photozincography has had much to answer for; misplaced economy, resulting in inferior material and a staff absolutely inadequate to deal with the mass of work thrust upon it, has completed the tale of ultimate inefficiency. We doubt if the wellmeant efforts of the committee will really do much to raise the low standard of Indian map publishing so long as cheap rates form the ruling motive of the publishing office. Partial engraving and heliozincography are steps in the right direction, however, but it has always appeared to us that the employment of a first-class firm in England to undertake all the finer work of the department is the real panacea for the ills that beset Calcutta map printing. There is no dealing with the inertness of the native by means of committees. Colonel Grant points out that one girl in England will do as much as two (native) men in the Calcutta ofiice. It may be so (so long as girls do not subscribe to trades unions), but he ignores the effects of a climate that affects Europeans and natives alike.

The general report on the Indian Survey for $1903-4{ }^{2}$ serves as a useful commentary on the recommendations of the committee which was sitting at the time that this rather belated report was under compilation. From it we are able to gather an idea of the enormous expansion in the widely diffused work of the department which has occurred within late years, and of the mass of material which has been crowded into the over-weighted publication offices. The report deals with certain administrative changes (such as the amalgamation of the forest surveys) which are unimportant when considered by the light of the subsequent recommendations of the committee; and much of it is concerned with the progress of cadastral, or revenue, surveys, which will in future probably form but an insignificant feature in the general programme.

Referring to the developments that are proposed in topographical (or military survey) branches of the department, we naturally turn to the map published in the report to illustrate the actual position of these surveys at present. The completion and maintenance of a $\mathrm{I}$-inch per mile map of the whole peninsula area, and the extension of accurate surveys into extra-peninsula regions, is one of the main features of the revised programme. The map, however, for this purpose is rather misleading, for we find a great part

I "General Report on the Operations of the Survey of India ar ministered under the Government of India dur'ng r $1903-4 . "$ By Col. J. R. Hobday, I.A. Pp. iv +62+xlii. (Calcutta : Office of the Superimtendent of Govern ment Printing, 1905.) Price 3 s.

No. I907, VOL. 74] 